\title{
CAPD 症例の離脱・死亡に関する検討
}

\begin{tabular}{llllll} 
金 原 幸 司 & 頼 岡 徳 在 & 小川 & 貴 彦 & 林 & \multicolumn{2}{c}{ 加野子 } \\
小 田 弘 明 & 山木戸 道郎 & 重本 & 憲一郎* & 原 & 田 知* \\
広島大学第 2 内科 & 一陽会原田病院* & & & &
\end{tabular}

key words: CAPD, 離脱, 死亡

〈要旨〉

Continuous ambulatory peritoneal dialysis (CAPD) は社会復帰という面において hemodialysis (HD) より優れ, 近年わが国でも増加傾向にあるが, 不幸にして離脱する症例も認められる. 并こで今回我々はCAPD から離脱, 死亡 した症例に関して検討した. 対象は 1985 年 8 月より 1991 年 10 月までの間に広島大学第 2 内科および一陽会原田病院 において導入した CAPD 症例 60 例(男性 37 例, 女性 23 例)であり, 1992 年 2 月の時点での転帰・予後を retrospective に検討した。なお 52 例は positive selection, 8 例は negative selection である. 60 例の内訳は死亡 5 例（ $8 \%$ ）, HD に移行 4 例（7％)，腎移植 2 例（3\%）であり，CAPD 継続症例は 49 例（82\%）であった，死亡原因は心筋梗塞， 心不全，脳出血，髄膜炎，自殺であったＨD に移行した 4 例中 3 例は腹膜炎が原因であった。死亡原因はさまざま であったが, HD に移行する原因としては腹膜炎が多く, CAPD の長期継続には適切な症例選択, 腹膜炎の予防が重 要と考えられた。

\section{Investigation of withdrawals and deaths in patients undergoing continuous ambulatory peritoneal dialysis}

Koji Kanahara, Noriaki Yorioka, Takahiko Ogawa, Kanoko Hayashi, Hiroaki Oda, Michio Yamakido, Kenichiro Shigemoto*, Satoru Harada*

Second Department of Internal Medicine, Hiroshima University School of Medicine; Ichiyokai Harada Hospital*

Continuous ambulatory peritoneal dialysis (CAPD) is superior to hemodialysis (HD) in terms of its morbidity rate. The use of CAPD in Japan has increased in recent years. Unfortunately, there are some drop-outs. This retrospective study investigated cases of withdrawal and death in 60 CAPD patients (37 males, 23 females) treated at Hiroshima University's Second Department of Internal Medicine and Ichiyokai Harada Hospital between August 1985 and October 1991. Fifty-two patients were selected positively and 8 patients negatively. Of the 60 patients, 49 remained on CAPD while the following drop-outs occurred : 5 due to death (8\%), 4 due to transfer to $\mathrm{HD}(7 \%)$ and 2 due to kidney transplantation $(3 \%)$. The deaths were related to myocardial infarction, heart failure, cerebral hemorrhage, meningitis and suicide. Three of the 4 patients transferred to HD due to peritonitis. Proper patient selection and the prevention of peritonitis are important factors in maintaining a patient on CAPD.

\section{緒言}

連続携行式腹膜透析 (continuous ambulatory peritoneal dialysis, CAPD) は社会復州という面において 血液透析 $(\mathrm{HD})$ より優れ ${ }^{1)}$, 近年わが国でも増加傾向に

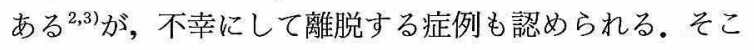
で今回我々は CAPD から離脱, 死亡した症例に関して検
討した。

\section{対象および方法}

対象は 1985 年 8 月より 1991 年 10 月までの間に広島 大学第 2 内科抒よび一陽会原田病院において導入した CAPD 症例 60 例で, 男性 37 例, 女性 23 例, 年齢は 17〜 73 歳, 平均 $46.4 \pm 13.3$ 歳であった。透析期間は 12

金原 幸司 広島大学第 2 内科干７34 広島市南区霞 1-2-3 (082-251-1111)

〔受付：平成 5 年 3 月 29 日, 受理：平成 5 年 7 月 23 日〕 
加月以下 13 例, $13 \sim 36$ 加月 27 例, $37 \sim 60$ か月 14 例, 61 か月以上 6 例であり, 1992 年 2 月の時点での転帰・予 後を retrospective に検討した。 なお 52 例は positive selection, 8 例は negative selection であった.

\section{結果}

60 例の内訳は死亡 5 例 ( $8 \%), \mathrm{HD}$ に移行 4 例 ( $7 \%$ ), 腎移植 2 例 ( $3 \%)$ であり, CAPD 継続症例は 49 例 (82\%) であった（表 1 ). 死亡原因は心筋梗塞, 自 殺, 脳出血, 䯣膜炎, 心不全であった (表 2)。HD に移 行した 4 例中 1 例は導入直後の腹膜機能不全であった が， 3 例は腹膜炎が原因であった (表 3 ). HD へ移行し た症例の多くは腹膜炎が原因であった。 そこで腹膜炎の 頻度を継続・離脱および positive・ negative selection に 区分して検討すると全体が 41.9 患者・月に 1 回に対して 継続例では 57.7 患者・月に 1 回, 離脱例では 12.6 患者・ 月に 1 回であった。これを CAPD 選択理由で分けると positive selection で50.3患者・月に 1 回, negative selection で 16.8 患者・月に 1 回であった（表 4).

\section{考察}

わが国においても健康保険適応が認められて以来, CAPD は HD とともに末期腎不全症例の治療法として 確立されてきた2)。しかしながら，不幸にして CAPDか ら離脱する症例も認められる。そこで今回我及は CAPD から離脱，死亡した症例に関して検討した。

Ataman $ら^{4)}$ は多施設の CAPD 症例を 4 年間で retrospective に検討し, 177 人のうち $24.9 \%$ が死亡し, $31.6 \%$ が HDに移行し， $26.0 \%$ が腎移植を受け，14.7\%が CAPD を継続しており，4 年以上 CAPD を施行できた 症例は $19.2 \%$ であり,HDに移行した主な原因は腹膜炎 であったと報告している. 本邦においては 1989 年 12 月 末の太田ら ${ }^{2)}$ の調查では CAPD からの脱落や移行例は 約 30\%であり,その原因としては腹膜炎が $47.7 \%$ と最も 多く, 本人ないしは家族の希望 $15.1 \%$, 除水困難 $13.5 \%$ などであった。岡田ら ${ }^{5} も 31$ 名の症例について同様の検 討を行っているが, $13 \%$ が死亡, $32 \%$ HD に移行，6\% が腎移植，48\%が CAPDを継続しており，HD に移行 した主な原因は腹膜炎であったと報告している。

我々の検討では死亡 $8 \%$, HD に移行 $7 \%$, 腎移植 3\%

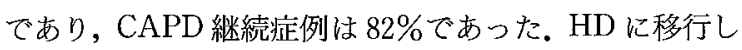
た 4 例中 1 例は導入直後の腹膜機能不全であったが， 3 例は腹膜炎が原因であった。このうち 1 例は結核性腹膜 炎であり，1例は acinectobacter による難治性の腹膜 炎， 1 例は再発を 5 回繰り返したため HD へ移行した。 な抢我々の CAPD 加ら HD への移行基準としては結核 菌, 真菌による腹膜炎あるいは難治性, 頻回再発例とし ている。これら症例は腹膜炎を合併しなければ CAPDを
表 1 CAPD 患者の転帰

\begin{tabular}{l|r|r}
\hline 継続 & 49 例 & $82 \%$ \\
\hline 死亡 & 5 例 & $8 \%$ \\
\hline HD に移行 & 4 例 & $7 \%$ \\
\hline 腎移植 & 2 例 & $3 \%$ \\
\hline \multicolumn{1}{|c|}{ 計 } & 60 例 & $100 \%$ \\
\hline
\end{tabular}

表 2 CAPD 患者の死因

\begin{tabular}{c|c|c|c|l|l}
\hline 症例 & 性 & 年齢 & 期間（月） & \multicolumn{1}{|l}{ 死因 } & 原疾患 \\
\hline & $\mathrm{M}$ & 55 & 2 & 心筋梗塞 & $\mathrm{DM}$ \\
\hline & $\mathrm{M}$ & 59 & 7 & 自殺 & $\mathrm{CGN}$ \\
\hline & $\mathrm{M}$ & 54 & 29 & 敛出血 & $\mathrm{CGN}$ \\
\hline & $\mathrm{M}$ & 59 & 35 & 㕼膜炎 & $\mathrm{CGN}$ \\
\hline & $\mathrm{M}$ & 64 & 55 & 心不全 & Gout \\
\hline
\end{tabular}

表 3 HD への移行原因

\begin{tabular}{c|c|c|c|l|l}
\hline 症例 & 性 & 年齢 & 期間 (月) & \multicolumn{1}{|c|}{ 移行原因 } & 原疾患 \\
\hline & $\mathrm{F}$ & 69 & 1 & 腹膜機能不全 & CGN \\
\hline & $\mathrm{F}$ & 61 & 6 & 結核性腹膜炎 & $\mathrm{CGN}$ \\
\hline & $\mathrm{F}$ & 23 & 10 & 腹膜炎 & SLE \\
\hline & $\mathrm{M}$ & 38 & 11 & 腹膜炎 & DM \\
\hline
\end{tabular}

表 4 腹膜炎の頻度

\begin{tabular}{l|c|c|c||c|c}
\hline & $\begin{array}{c}\text { 全体 } \\
\mathrm{n}=60\end{array}$ & $\begin{array}{c}\text { 継続 } \\
\mathrm{n}=48\end{array}$ & $\begin{array}{c}\text { 離脱 } \\
\mathrm{n}=12\end{array}$ & $\begin{array}{c}\text { positive } \\
\mathrm{n}=52\end{array}$ & $\begin{array}{c}\text { negative } \\
\mathrm{n}=8\end{array}$ \\
\hline 患者数 & 23 & 17 & 6 & 18 & 5 \\
\hline 回数 & 40 & 26 & 14 & 30 & 10 \\
\hline$(1 /$ 患者・月 $)$ & $1 / 41.9$ & $1 / 57.7$ & $1 / 12.6$ & $1 / 50.3$ & $1 / 16.8$ \\
\hline
\end{tabular}

さらに継続できた可能性があり, 腹膜炎の予防は CAPD を長期継続するために最も重要であると考えられた。 我々の成績で HD への移行が少なく CAPD 継続が多い のは positive selection の症例が多いためと考えられ る ${ }^{6,7)}$.このことは腹膜炎の頻度が positive selection で 50.3 患者・月に 1 回, negative selection で 16.8 患者・ 月に 1 回であったことより, positive selection 症例は病 識も十分にあり,かつ CAPD バッグ交換手技に対する理 解度も優れており, 成績の向上につながっていると考元 られる. システムの問題に関しては今回腹膜炎が原因で $\mathrm{HD}$ へ移行した症例はUV フラッシュやディスコネクト システムではなく全てスタンダードシステムを使用して いた. CAPD の腹膜炎に関して頼岡ら ${ }^{8,9}$ は症例選択, CAPDシステムの改良, 腹膜炎の治療法の改善などによ 
り腹膜炎の頻度の減少および腹膜炎による HD への移 行を減少できるとしており，今後腹膜炎の合併の減少に より，CAPD はさらに普及するとともにより長期に継続 可能と考えられる.

一方, CAPD 症例の死亡原因は心筋梗塞, 自殺, 脳出 血, 䯣膜炎，心不全であり，CAPD に特異的なものはみ られず，死亡率の減少に関してはそれぞれの症例に対す る対応が必要と考えられる。

\section{結語}

CAPD 症例の死亡原因はさまざまであるが, CAPD か ら離脱して HD に移行する原因としては腹膜炎が多く， CAPD の長期継続には適切な症例選択, 腹膜炎の予防が 重要と考えられる。

なお本論文の要旨は第 37 回日本透析療法学会総会に扔い て発表した.

\section{文献}

1) Wolcott DL, Nissenson AR: Quality of life in chronic dialysis patients : A critical comparison of continuous ambulatory peritoneal dialysis (CAPD) and hemodialysis. Am J Kidney Dis 11 : 402-412, 1988

2）太田和夫, 川口良人, 鈴木利昭, 河合達郎：1980 年 より 10 年間にわたるわが国における CAPD 治療の
実態調查. 腎と透析 30：759-767，1991

3）原田孝司, 原 耕平：CAPD の合併症と予後. 医学 のあゆみ 159：69-73，1991

4) Ataman R, Burton PR, Gokal R, Brown $\mathrm{CB}$, Marsh FP, Walls J : Long-term CAPD-some U. K. experience. Clin Nephrol 30 : s71-s75, 1988

5）岡田一義, 矢内 充, 久野 勉, 奈倉勇爾, 高橋 進, 波多野道信：CAPD とその限界一我々の経験より 一. 透析会誌 $23 ： 1363-1365 ， 1990$

6）須賀孝夫，中島桂子，遠藤正之，野本保夫，堺，秀 人：CAPD 導入時の患者選択の重要性と腹膜炎の 発症に関する研究。透析会誌 $22 ： 865-869,1989$

7）久保和雄, 田中好子, 仲里 聰, 加藤満利子, 二瓶 宏：CAPD 適応症例の選択と導入時期の決定. 日本 臨牀 49：478-483，1991

8）頼岡徳在，小川貴彦，金原幸司，小田弘明，奥新小 百合, 大平法尚, 浜口直樹, 和田浩治, 山木戸道郎： 広島大学第二内科における持続性自己管理腹膜透析 (CAPD) 患者の腹膜炎に関する検討. 広島医学 43 ： 1521-1523，1990

9）頼岡徳在，小川貴彦，武政敦夫，小田弘明，金原幸 司，大平法尚，平林 晃，山木戸道郎：CAPD 患者 腹膜炎に対するバンコマイシン腹腔内投与療法の有 用性に関する検討。腎と透析 33：1129-1133，1992 